\title{
Pawai Miniatur Truk sebagai Arena Hiburan Baru Masyarakat Rural: Sebuah Praktik Sosial
}

\author{
Dadang Fredianto ${ }^{\mathrm{a}, 1^{*}}$, Fariz Eko Septiawan ${ }^{\mathrm{b}, 2}$, \\ a Mahasiswa Magister Ilmu Sosial, Universitas Brawijaya, Kota Malang, Jawa Timur 65145 \\ b Staf Kementerian Koordinator Bidang Pembangunan Manusia dan Kebudayaan, DKI Jakarta 10110 \\ ${ }_{1}^{1}$ fredianto.dadang@gmail.com; 2 faris@webmail.umm.ac.id \\ * Corresponding Author
}

\begin{tabular}{ll}
\hline INFO ARTIKEL & ABSTRAK \\
\hline Sejarah Artikel: & Pawai miniatur truk telah menjadi hiburan baru bagi masyarakat pedesaan di \\
Diterima: 28 Februari & Jawa Timur bagian Selatan. Para peserta membuat miniatur truk lengkap \\
2020 & dengan aksesoris dan desain interior yang dibuat semirip mungkin dengan \\
Direvisi: 6 Maret 2020 & aslinya. Para pecinta miniatur truk menampilkan karya mereka di acara \\
Disetujui: 18 Maret 2020 & karnaval untuk memperebutkan hadiah dan pengakuan dari komunitasnya. \\
Tersedia Daring: 12 April & Dalam memahami fenomena tersebut, pengamatan langsung, baik dalam \\
2020 & karnaval maupun dalam media sosial dilakukan. Selain itu, wawancara kepada \\
\hline Kata Kunci: & penggemar dilakukan. Wawancara dilakukan pada saat karnaval digelar di \\
Karnaval & Desa Bagelenan Kabupaten Blitar dan di Desa Purwodadi Kabupaten Kediri. \\
Pawai Miniatur Truk & Tulisan ini bertujuan memahami fenomena pawai miniatur truk sebagai \\
Praktik Sosial & sebuah praktik sosial. Untuk melakukan hal teresebut digunakan teori Praktik \\
Rekonversi Modal & Sosial Pierre Bourdieu. Penelitian menunjukkan bahwa terdapat modal \\
Rural & ekonomi, modal simbolik, dan modal budaya yang digunakan penggemar \\
& dalam melakukan praktik miniatur truk. Segala aktivitas ini disebut sebagai \\
& konsep habitus. Modal dan habitus yang dimiliki oleh penggemar miniatur \\
& tersebut mereka mainkan ke dalam sebuah arena, di mana arena merupakan \\
& tempat pertarungan para penggemar dalam merebutkan sumber daya. \\
& Pembahasan ini menemukan sebuah konsep baru tentang praktik sosial dalam \\
& hiburan masyarakat rural, yaitu pawai miniatur truk telah menjadi sebuah \\
praktik sosial warga pedesaan di daerah Jawa Timur Selatan.
\end{tabular}

\begin{tabular}{ll}
\hline & ABSTRACT \\
\hline $\begin{array}{l}\text { Keywords: } \\
\text { Capital Conversion }\end{array}$ & The miniature truck parade has become a new entertainment in rural \\
Carnaval & communities in southern East Java. The participants made a miniature truck \\
Miniature Truck Parade & complete with accessories and interior design that was made as closely as \\
Rural & possible to the original. Truck miniature lovers display their work at carnivals \\
Social Practice & understanding this phenomenon, direct observations both in the carnival and \\
& in social media are carried out. In addition, interviews with fans are very \\
& necessary. Interviews were conducted during the carnival that was held in \\
& Bagelenan Village, Blitar Regency and in Purwodadi Village, Kediri Regency. \\
& Because this paper combines phenomena with theory, The field findings were \\
& analyzed using the theory of Social Practice from Pierre Bourdieu. Research \\
& shows that there is economic capital, symbolic capital and cultural capital used \\
& by fans in practicing miniature trucks. All these activities are referred to as the \\
concept of habitus. Capital and habitus owned by these miniature fans they \\
play into an arena, where the arena is a place where fans fight for resources. \\
This discussion discovers a new concept of social practice in the \\
entertainment of rural communities. Where the miniature truck march has \\
become a social practice for rural residents in southern East Java.
\end{tabular}


How to Cite: Fredianto, D., \& Septiawan, F. E. (2020). Pawai Miniatur Truk sebagai Arena Hiburan Baru Masyarakat Rural: Sebuah Praktik Sosial. JURNAL SATWIKA, 4 (1), 10-20 doi: https://doi/org/10.22219/SATWIKA.Vol4.No1.10-21

\section{Pendahuluan}

Hiburan telah menjadi kebutuhan masyarakat global. Semakin padatnya aktivitas manusia menuntut mereka untuk mencari alternatif dalam mengatasi kejenuhan. Selain itu, faktor kegemaran turut andil dalam memutuskan kebutuhan akan hiburan. Dunia hiburan pun saat ini semakin beragam sesuai dengan segmen pasar. Hal ini tidak terlepas dari faktor perkembangan zaman yang sangat masif. Di antara jenis hiburan yang tersedia, hiburan yang melibatkan banyak orang dan selalu menarik banyak pengunjung yaitu karnaval.

Di Indonesia, karnaval telah menjadi hiburan yang menyatu dalam kehidupan masyarakat. Hal ini dikarenakan masyarakat Indonesia sangat senang dan antusias dengan kemeriahan. Merunut sejarah, masyarakat tradisi Nusantara telah mengenal seni pertunjukan/performance art yang dipertontonkan di jalanan sehingga mengundang masyarakat datang berkerumun untuk mengapresiasi di kiri-kanan jalan (Denissa, Pialang, Widodo, \& Adidsasmito, 2016). Menurut Debord (dalam Denissa, Widodo, Adisasmito, \& Piliang, 2015), masyarakat Indonesia sebagian besar adalah masyarakat kacamata, berarti orang yang suka menonton dan ditonton, serta nilai-nilai sosial budaya dapat dipelajari dan dipahami dari sebuah tontonan. Oleh karenanya, karnaval merupakan wadah yang tepat bagi karakteristik masyarakat Indonesia dalam mengejawantahkan kekayaan seni dan budaya yang ada.

Kekayaan seni dan budaya Indonesia menempatkan karnaval sebagai hilir pertunjukkan ekspresi dan kreativitas masyarakat. Puncak kemeriahan karnaval biasanya dilaksanakan pada saat peringatan
Hari Ulang Tahun (HUT) Kemerdekaan Republik Indonesia. Namun, dalam perkembangannya, saat ini karnaval tidak hanya dilaksanakan dalam rangka hari peringatan kemerdekaan saja, melainkan juga dilaksanakan sesuai dengan keinginan atau kebutuhan para penyelenggaranya.

Metamorfosa karnaval tidak hanya dapat dilihat dari waktu pelaksanaannya, tetapi juga materi atau tema yang dibawakan. Jika dahulu karnaval menampilkan berbagai macam karya seni dan kreativitas, kini spesialisasi karnaval merambah pada tematema tertentu, misalnya fashion. Saat ini, karnaval dengan tema khusus seperti pada Jember Fashion Carnaval, Solo Batik Carnival, dan Banyuwangi Ethno Carnival. Karnaval-karnaval tersebut digelar tahunan dan telah membudaya.

Spesifikasi tema karnaval nampaknya terus mengalami evolusi. Tidak cukup dalam hal fashion, kini tema baru dan unik muncul dalam masyarakat rural di daerah Jawa Timur bagianSelatan, seperti Kabupaten Malang, Kabupaten Blitar, Kabupaten Kediri, dan Kabupaten Tulungagung. Dalam kurun waktu tiga tahun terakhir, karnaval miniatur truk muncul dan kemudian mewabah di kalangan masyarakat pedesaan di daerahdaerah tersebut. Banyak masyarakat yang mengikuti euforia dalam arak-arakan miniatur truk, membentuk komunitaskomunitas yang terdiri dari anak-anak muda. Komunitas tersebut sebagian besar dibentuk berdasarkan persamaan geografis, misalnya satu desa atau kecamatan.

Fenomena miniatur truk sangat menarik untuk diteliti karena fenomenanya baru tetapi langsung menarik minat banyak masyarakat. Berbeda dengan karnaval pada umumnya, pawai miniatur truk digelar pada malam hari 
dan bisa selesai pada pagi hari. Banyak masyarakat yang heran, betapa cintanya para penggemar tersebut, namun sulit untuk dijelaskan apa yang membuat penggemar begitu mencintai miniatur truk. Padahal, biaya untuk mendesain sebuah miniatur truk terbilang cukup mahal, yaitu sekitar 3-5 juta rupiah (Hadi, 2018).

Budaya baru miniatur truk sering dijumpai di daerah Jawa Timur bagian Selatan, seperti yang telah dijelaskan pada paragraf sebelumnya. Gelaran pawai biasanya diadakan oleh komunitas, instansi swasta, maupun instansi pemerintah. Berdasarkan hal tersebut, penelitian ini bertujuan untuk memahami fenomena pawai miniatur truk mini sebagai sebuah praktik sosial. Dalam penelitian ini diambil beberapa sampel pagelaran pawai miniatur truk, yaitu pawai/karnaval yang digelar di Desa Bagelenan Kecamatan Srengat Kabupaten Blitar, dan di Desa Purwodadi Kecamatan Ringinrejo Kabupaten Kediri. Dua daerah ini merupakan basis komunitas yang warganya secara kuantitas banyak yang menjadi penggemar miniatur truk.

Penelitian terkait dengan pagelaran miniatur truk pernah dilakukan oleh Wahjuni and Al-Balya (2020) dengan judul "Parade Miniatur, Potensi Pariwisata Berbasis Komunitas di Kabupaten Kediri”. Penelitian tersebut membahas mengenai potensi pariwisata yang bisa dikembangkan karena adanya pawai miniature dengan berfokus pada Community Bassed Management. Penelitian tersebut hanya dilakukan di satu desa, yaitu di Desa Slumbung, Kecamatan Ngadiluwih Kabupaten Kediri. Berbeda dengan penelitian tersebut, penelitian yang dilakukan oleh penulis lebih menonjolkan sisi teoretis dan analitis yang dipadukan oleh hasil temuan lapang. Penelitian ini menggambarkan secara holistik bagaimana fenomena miniatruk truk menjadi sebuah budaya baru.

Penelitian ini menggunakan teori Praktik Sosial yang digagas oleh Pierre Bourdieu sebagai pisau analisis. Pemikiran Bourdieu sangat berpengaruh dalam bidang ilmu sosial, terlebih dalam kajian budaya.
Teori yang dikemukakan oleh Bourdieu dikenal juga dengan teori praktik. Teori ini merupakan perpaduan teori yang berpusat pada agen atau aktor dengan teori yang berpusat pada struktur dalam membentuk kehidupan sosial (Siregar, 2016).

Konsep penting dalam teori praktik Bourdieu, yaitu habitus, arena/ranah/medan (field), kekerasan simbolik (symbolic violence), modal (capital), dan strategi (strategy). Dari beberapa konsep tersebut, konsep hatibus, ranah, dan modal yang akan merepresentasikan fenomena miniatruk truk. Habitus digambarkan sebagai sebuah kebiasaan masyarakat, di mana kebiasaan tersebut akan dipadukan dengan modalmodal yang dimiliki dan saling bertarung di sebuah arena.

Tulisan ini memadukan temuan hasil lapang berupa fenomena miniatur truk dengan konsep-konsep yang diperkenalkan oleh Bourdieu, sehingga hasil yang didapat dalam tulisan ini berupa analisis fenomena sosial menggunakan sebuah teori. Karenanya, pembahasan dalam tulisan ini lebih bersifat teoretis meskipun berangkat dari sebuah fenomena konkrit.

\section{Metode}

Penelitian ini menggunakan pendekatan kualitatif dengan teknik pengumpulan data berupa observasi lapang, wawancara, studi media, serta studi literatur. Penelitian lapang berupa observasi dilakukan untuk mengetahui secara langsung fenomena pawai miniatruk truk. Waktu pengumpulan data dilakukan pada bulan Juli dan November 2019 dengan mengobservasi langsung dalam acara karnaval dan mewawancarai 5 orang informan secara insidental di masing-masing karnaval. Wawancara dimaksudkan untuk menggali informasi secara mendalam terkait pagelaran miniatur truk.

Lima orang informan di masing-masing karnaval, yang artinya total informan 10 orang, dinilai cukup untuk memberikan informasi. Hal ini dikarenakan para penggemar miniatur truk memiliki pemahaman dan kebiasaan yang sama terkait dunia perminiaturan. Adapun observasi dan 
wawancara dilakukan pada acara karnaval yang diselenggarakan di Desa Bagelenan Kecamatan Srengat Kabupaten Blitar pada tanggal 20 Juli 2019, dan karnaval yang diselenggarakan di Desa Purwodadi Kecamatan Ringinrejo Kabupaten Kediri pada tanggal 17 November 2019.

Selain observasi langsung ke lapangan dan wawancara, penelitian ini juga menggunakan data yang berasal dari media sosial, baik Facebook maupun Youtube. Adapun data yang diperoleh dari Facebook berasal dari grup-grup miniatur truk seperti, Miniatur Truk Ngunut Tulungagung (Facebook, 2020d), Komunitas Miniatruk Truk Blitar Raya (Facebook, 2020a), Pecinta Miniatur Sound System dan Truk Plat AG (Facebook, 2020e), Komunitas Miniatur Kediri Selatan (Facebook, 2020b), Komunitas Sound Miniatur Truk Malang Raya (Facebook, 2020c). Adapun data yang diperoleh dari Youtube berasal dari kanal milik Haris Setyawan, Guguh Santoso (Santoso, 2019), Astronik Blitar (Blitar, 2019), KSJ Audio Malang (Malang, 2019), Edi Sutik (Sutik, 2020), dan Ibnu SBT (Ibnu, 2018)..

Studi literatur diperlukan untuk memperdalam kaidah teori yang digunakan dalam menganalisis fenomena miniatur truk, dalam hal ini adalah teori Praktik Sosial yang diperkenalkan oleh Pierre Bourdieu. Waktu untuk melalukan studi media dan studi literatur adalah di antara bulan Juli hingga November 2019. Teknik analisa data yang digunakan dalam penelitian ini adalah teknik analisa data kualitatif yang dimulai dari mempersiapkan data, membaca data, dan mengolahnya. Aktivitas ini dilanjutkan dengan menganalisis data lebih rinci dengan cara mengkoding, yaitu memberi pengkodean data yang memegang peranan penting dalam proses analisis data. Proses selanjutnya dengan menampilkan data dan diakhiri dengan penarikan kesimpulan.

\section{Hasil dan Pembahasan}

\subsection{Fenomena Pawai Miniatur Truk}

Miniatur truk di Jawa Timur Selatan menjadi hiburan baru yang viral. Setidaknya, miniatur truk ini sangat booming di kalangan anak muda rural di sekitaran Kabupaten Malang, Blitar, Kediri, serta kabupatenkabupaten di sekitarnya. Demi sebuah miniatur truk, pecintanya tidak segan mengeluarkan biaya yang besar. Mereka membuat replika truk mirip dengan aslinya. Mulai perincian bodi, ban, lampu, kaca depan, bahkan interiornya seperti ruang kemudi dibuat mirip dengan aslinya. Hal yang juga tidak pernah ketinggalan adalah kendaraan inijuga dilengkapi dengan lampu kerlap-kerlip dan susunan sound system lengkap yang digunakan untuk meramaikan karnaval. Itulah mengapa biaya pembuatan sebuah miniatur truk tidak bisa dibilang murah, yaitu berkisar 3-5 juta rupiah (Hadi, 2018).

Para pecinta miniatur truk menampilkan karyanya dalam balutan acara karnaval. Karnaval diadakan secara khusus untuk mewadahi para pencinta miniatur truk. Penyelenggaranya bisa berasal dari berbagai latar belakang, seperti sesama komunitas pecinta miniatur truk, instansi pemerintah, maupun kelompok masyarakat lainnya. Miniatur truk ditampilkan dengan cara menarik bodi miniatur truk dari depan dan diarak seperti pawai. Karnaval tersebut pada umumnya dilombakan dengan memperebutkan hadiah. Uniknya, hadiahhadiah yang diperebutkan kadang tidak sebatas hadiah yang ada pada umumnya, seperti uang, namun juga hadiah unik berupa hewan seperti anak kambing.

Daya tarik karnaval miniatur truk tidak bisa dijelaskan secara spesifik. Setiap pecinta miniatur memiliki alasan tersendiri hal yang membuat mereka suka akan hal yang sedang digandrunginya tersebut (lihat Gambar 1). Namun secara umum selain hasil keindahan miniatur truk, saling membunyikan sound system dengan volume yang besar serta diiringi musik DJ remix khas masyarakat kampung turut andil dalam menarik penonton. Fenomena ini mungkin aneh bagi yang bukan pecinta miniatur truk. Ditambah lagi, durasi karnaval yang rata-rata sangat panjang hingga tengah malam, menambah 
persepsi "aneh" akan fenomena tersebut bagi masyarakat non pecinta miniatur.

Keunikan dan keanehan inilah yang membuat fenomena karnaval miniatur truk layak disebut baru dan beda karena sangat berbeda dengan karnaval konvensional pada umumunya. Artinya, karnaval miniatur truk telah menambah khasanah kebudayaan baru

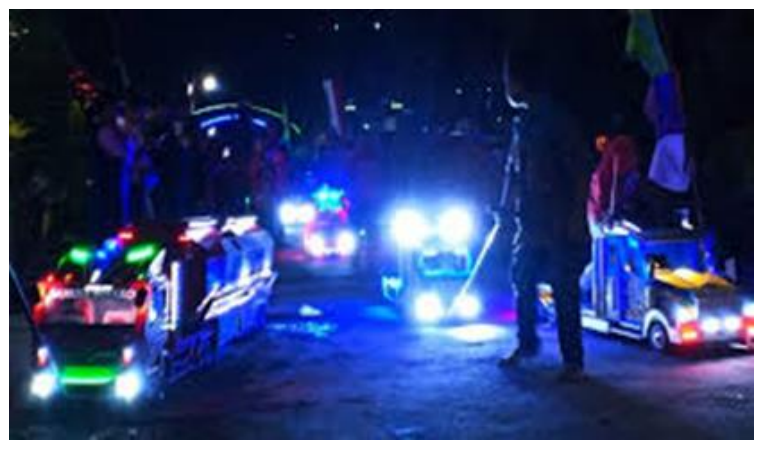

Gambar 2 Konvoi Miniatur Truk Saat Karnavali (Dokumentasi Penulis, 2020)

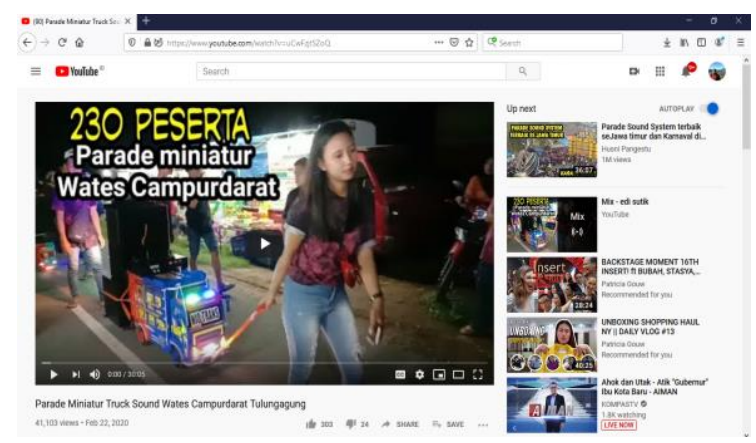

Gambar 3 Salah Satu Kanal Youtube Komunitas Truk Mini (Sumber: Dokumentasi Penulis, 2020)

Meskipun segmen karnaval miniatur truk sebagian besar terdiri dari kaum milenial yang berasal dari lingkungan masyarakat rural, penggunaan media sosial seperti Facebook maupun Youtube (lihat Gambar 3) tidak bisa terhindarkan. Komunitas mereka selain secara fisik atau tatap muka, juga membentuk komunitas digital seperti grup di Facebook (lihat Gambar 4), yang keanggotaannya lebih banyak dan tidak sekadar dalam satu wilayah kecil. Hal itu menandakan bahwa komunitas yang mereka bangun benar-benar berdasarkan tujuan yang sama walaupun dibatasi oleh ruang geografis. Seperti apa yang dikatakan oleh William dan Lawson (dalam Windarti, 2016), bahwa pada masyarakat khas pedesaan (lihat Gambar 2). Hal ini membuktikan bahwa masyarakat pedesaan, khususnya di daerah Jawa Timur Selatan, dewasa ini senantiasa mengalami perkembangan budaya. Media sosial seperti Youtube dan Facebook turut membantu mereka dalam hal bertukar informasi seputar perkembangan dunia miniatur truk.

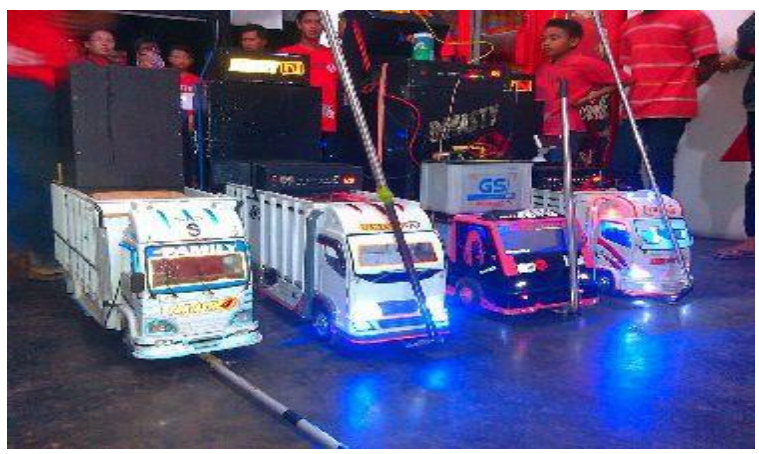

Gambar 1 Miniatur Truk pada Ajang Karnaval (Sumber: Dokumentasi Penulis, 2020)

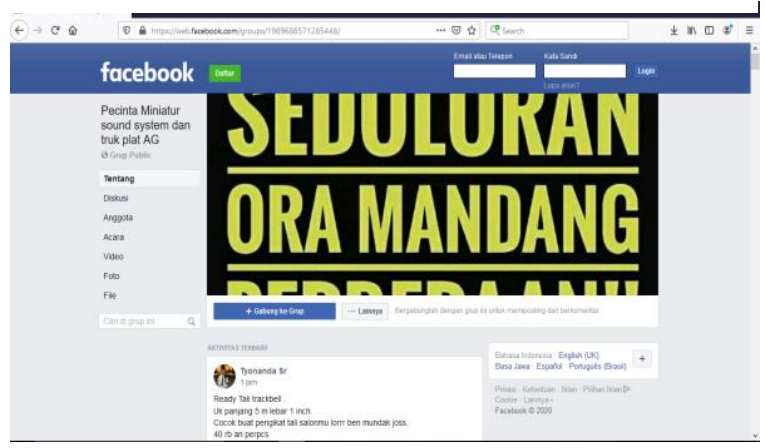

Gambar 4 Salah Satu Grup Facebook Komunitas Truk Mini (Sumber: Dokumentasi Penulis, 2020)

komunitas adalah sekelompok orang yang memiliki tujuan dan pendapat yang sama serta tidak selalu dalam area yang sama.

Sementara itu, Youtube sebagai media sosial berbasis video digunakan oleh pecinta miniatur truk sebagai media sharing maupun cross-learning dari hasil karya komunitas lain. Video-video tentang karnaval miniatur truk dapat dengan mudah ditemukan di Youtube. Hal ini menandakan bahwa kemajuan teknologi tidak hanya bisa dilihat sebagai ancaman bagi hiburan non-digital, tetapi justru dapat dimanfaatkan sebagai media penyebaran informasi. Setidaknya melalui Youtube-lah eksistensi miniatur truk semakin fenomenal. 
Fenomena pawai miniatur truk juga dimanfaatkan oleh masyarakat ataupun instansi dalam mengisi berbagai acara sebagai hiburan atau tontonan. Misalnya, dalam acara Pesta Rakyat dan Gebyar Jalan Sehat Arema Sadar Pajak V 2018 yang diselenggarakan Badan Pelayanan Pajak Daerah (BP2D) Kota Malang/ Pada kegiatan ini penyelenggara mengundang sejumlah 75 penggemar miniatur truk untuk menampilkan miniatur truknya (Ratri, 2018). Dalam acara lain, pada saat pemilihan presiden dan anggota legislatif tahun 2019 yang lalu, salah satu Tempat Pemungutan Ssuara (TPS) di Desa Ngadirenggo, Kecamatan Wlingi Kabupaten Blitar mengangkat miniatur truk sebagai tema utama. Hal ini bertujuan untuk mengangkat potensi desa tersebut (Dona, 2019).

\subsection{Pawai Miniatur Truk sebagai Arena Produksi Kultural}

Karnaval minatur truk benar-benar telah menjelma menjadi arena budaya baru bagi masyarakat rural di daerah Jawa Timur Selatan. Budaya tersebut menyatu dalam masyarakat dan termanifestasikan dalam aktivitas-aktivitas memainkan miniatur truk, sementara karnaval merupakan sebuah arena dalam mengejawantahkan segala aktivitas tersebut. Fenomena miniatur truk ini sangat menarik untuk dilakukan sebuah identifikasi mendalam, khususnya apabila dikaitkan dengan konsep atau teori sosiologi berbasis budaya. Arena budaya yang terkonstruksi merupakan representasi dari istilah praktik sosial Pierre Bourdie. Karnaval miniatur truk adalah sebuah proses sosial masyarakat dalam mengonstruksi sebuah budaya dan mencoba eksis di dalam arenanya. Dengan pendekatan sosiologi budaya Pierre Bourdieu, fenomena miniatur truk secara lebih mendalam diaparkan berikut.

Bourdieu menjelaskan dalam menganalisis praktik sosial aktor dapat dilihat melalui modal, habitus, dan ranah/arena yang mereka gunakan. Habitus adalah struktur mental atau kognitif yang dengannya orang berhubungan dengan dunia sosial. Orang dibekali dengan serangkaian skema internalisasi yang mereka gunakan untuk mempersepsi, memahami, mengapresiasi, dan mengevaluasi dunia sosial. Melalui skema ini, orang menghasilkan praktik mereka, mempersepsi dan mengevaluasinya. Secara dialektis, habitus adalah "produk dari internalisasi struktur" dunia sosial. Habitus diperoleh sebagai akibat dari ditempatinya posisi di dunia sosial dalam waktu yang panjang (Ritzer \& Goodman, 2010). Dalam bahasa sederhana, habitus adalah segala aktivitas aktor dalam kesehariannya yang merupakan hasil dari proses belajar atau sosialisasi dengan dunia sosialnya.

Konsep modal bagi Bourdieu terdapat beberapa jenis modal yang dipertaruhkan dalam arena yakni modal ekonomi, modal sosial, modal budaya, dan modal simbolik. Modal ekonomi mencakup hal-hal seperti alat-alat produksi, materi, dan uang yang dengan mudah digunakan untuk segala tujuan serta diwariskan dari satu generasi ke generasi berikutnya. Modal budaya ialah yang termasuk dalam keseluruhan kualifikasi intelektual yang direproduksi secara formal maupun warisan keluarga. Modal sosial termanifestasikan melalui hubunganhubungan dan jaringan yang terbentuk melalui ranah yang merupakan sumber daya yang berguna dalam penentuan dan reproduksi kedudukan-kedudukan sosial. Kemudian, modal simbolik mencakup segala bentuk prestise, status, otoritas, dan legitimasi (Wati, 2015).

Ranah (field/arena) lebih dipandang Bourdieu secara relasional dari pada secara struktural. Ranah adalah jaringan relasi antarposisi objektif di dalamnya. Keberadaan relasi-relasi ini terpisah dari kesadaran dan kehendak individu (Ritzer \& Goodman, 2010). Modal dan habitus akan dipertaruhkan dalam sebuah ranah yang merupakan arena kekuatan yang di dalamnya terdapat upaya perjuangan untuk memperebutkan sumber daya (modal) dan juga untuk memperoleh akses tertentu yang dekat dengan hierarki kekuasaan. Dari ketiga komposisi tersebut, maka Bourdieu merumuskan bahwa Praktik 
Sosial $=($ Habitus $\mathrm{x}$ Modal $)+$ Ranah $($ Wati, 2015).

Dalam kaitannya dengan fenomena Pawai Miniatur Truk dapat diamati bahwa modal adalah kunci utama yang dibawa aktor ke arena. Modal adalah dasar yang berfungsi untuk membentuk dan mempertahankan tatanan sosial (Bourdieu, 2002). Para penggemar miniatur truk sebagai aktor yang bertanding dalam arena karnaval, mempunyai sumber daya baik ekonomi, simbol, sosial, dan budaya. Modal ekonomi ditunjukkan oleh para penggemar miniatur dengan mengorbankan materiil (uang) untuk membuat sebuah miniatur truk. Tidak tanggung-tanggung, biaya yang dikeluarkan tidaklah sedikit. Biaya pembuatan satu miniatur truk lengkap dengan aksesoris, lampu kerlap-kerlip, sound system setidaknya membutuhkan dana minimal 3 juta rupiah. Biaya tersebut kemudian bervariasi berdasarkan desain, kerumitan, dan kelengkapan. Modal ekonomi di sini terlihat sangat dominan karena miniatur truk sendiri memang membutuhkan kreativitas dan biaya. Semakin miniatur truk terlihat bagus dan unik, maka semakin besar pula biaya yang dibutuhkan.

Antusiasme yang ditunjukkan oleh masyarakat dalam membuat miniatur truk dengan biaya mahal merupakan suatu bentuk peranan komunitas dalam pembangunan pariwisata. Wahjuni and Al-Balya (2020) menyebutkan bahwa komunitas merupakan aktor utama dalam pembangunan pariwisata guna untuk meningkatkan standar kehidupan masyarakat. Hal ini didasarkan pada kepentingan pragmatis untuk mendapatkan keuntungan secara finansial. Logika seperti ini dibangun atas dasar asumsi klasik Marxian terkait suatu aktivitas didorong oleh determinisme ekonomi semata. Sementara kajian ini lebih mendalam dengan melihat keseluruhan fenomena sebagai pertarungan simbolik dengan memnfaatkan modal ekonomi, modal sosial, dan modal simbolik. Bourdieu lebih melihat bahwa kekuasaan di dalam masyarakat tidak bersifat hierarkis tapi lebih kepada konfigurasi berdasar kepemilikan dan komposisi modal.
Perspektif khas inilah yang digunakan Bourdieu menyingkap dominasi simbolis (praktik kuasa dalam konteks simbolis) terkait kepentingan-kepentingan dominatif dibalik selera budaya.

Sementara itu, modal berupa simbol menurut Bourdieu di mana status atau prestise merupakan entitas yang dikedepankan nampaknya juga trerlihat dalam fenomena miniatur truk. Dalam arena pawai miniatur truk, ternyata ada kelompokkelompok atau komunitas yang menjadi panutan bagi penggemar miniatur lainnya. Kelompok tersebut secara prestise memiliki jam terbang yang tinggi dalam arena karnaval atau dalam kata lain telah memiliki "nama" dalam dunia perminiaturan. Nama atau prestise tersebut dipengaruhi oleh lamanya komunitas tersebut eksis, banyaknya karnaval yang telah diikuti, dan variasi desain miniatur yang ditampilkan. Faktor tersebutlah yang setidaknya membuat para penggemar miniatur sebenarnya memiliki struktur sendiri apabila dilihat dari prestise. Sebagai contoh, kelompok yang telah lama berkecimpung dalam arena miniatur tentu memiliki nilai sosial yang lebih tinggi dari pada yang masih baru bergabung.

Modal simbolik menjadi penting karena merupakan suatu bentuk komunikasi nonverbal yang mewakili makna dari penyandangnya. Tanda dan simbol tersebut akan mengukuhkan status dari pemiliknya yang bisa digunakan untuk mempertahankan dominasinya dalam suatu komunitas. Studi yang dilakukan Hasanah (2019) misalnya menemukan suatu indikasi bahwa Warak Ngendog yang merupakan kreativitas suatu budaya lokal berupa patung binatang rekaan yang terdiri dari tiga unsur utama, yaitu kepala, leher, dan badan memiliki maknamakna yang sesuai dengan karakteristik mereka. Kata Warak Ngendog berasal dari bahasa Arab waro'a, wariq yang berarti menghindari yang dilarang oleh Allah SWT. Arak-arakan Warak Ngendog dijadikan sebuah media dakwah visual yang ada sejak tahun 1881 dan terus dilestarikan sampai sekarang yang menjadi maskot dalam ritual dugderan masyarakat Kota Semarang. Ritual 
tersebut tetap dilaksanakan hingga sekarang dikarenakan adanya konstruksi pada ruang sosial (social space) berdasarkan adanya hierarki komposisi dari keseluruhan modal ekonomi, budaya, dan sosial (Atkinson dalam Hasanah, 2019).

Modal simbolik nampaknya sangat berhubungan dengan modal sosial dan budaya. Simbol berupa prestise atau "nama besar" sebuah komunitas miniatur memiki jaringan sosial yang lebih intens di antara para penggemar miniatur. Mereka membentuk sebuah relasi sosial di antara para penggemar untuk saling menguatkan modal yang mereka miliki. Relasi sosial di antara para penggemar miniatur truk cenderung bersifat konstruktif, karena mereka disatukan oleh sebuah kesamaan kesenangan/hobi. Jika seorang penggemar miniatur memunculkan ide atau karya baru, pastilah ide tersebut sebagai hasil dialog para penggemarnya. Atau juga bisa terjadi jika seorang penggemar miniatur truk memiliki sebuah ide baru, maka ide tersebut akan ditularkan kepada penggemar miniatur yang lain. Relasi sosial inilah yang kemudian membentuk sebuah pola relasi sosial tersediri, di mana sebenarnya mereka telah membentuk suatu budaya penggemar miniatur truk. Di sinilah modal berupa budaya tersebut dibentuk.

Hal ini juga senada dengan penelitian yang dilakukan oleh Syaifuddin, Qodariah, and Naredi (2019) yang dibentuk dan dirawat menggunakan modal sosial. Komunitas dibentuk diawali dengan saling bertukar informasi di antara penggemar motor tua kemudian terbentuk suatu komunitas yang pada akhirnya menjelma menjadi sebuah gaya hidup. Gaya hidup komunitas ini lebih berorientasi kepada kebebasan berekspresi yang ditampilkan melalui cara berpakaian, gaya rambut, gaya berbicara, dan kebiasaan yang tampak dari anggotanya yang digunakan untuk menjadikan gaya alternatif (counter style) terhadap budaya mainstream. Komunitas ini bisa tetap eksis dikarenakan ada modal sosial berupa solidaritas mekanik seperti rasa kepercayaan, kebersamaan, kesetiakawanan, dan persaudaraan yang diwujudkan dengan membantu sesama anggota apabila terkena musibah. Mereka juga memiliki semboyan perekat yaitu "We All Brothers". Selain itu juga adanya norma yang ada yaitu menjaga hubungan baik dengan sesama anggota komunitas, loyal, dan berpartisipasi aktif dalam setiap kegiatan komunitas sehingga interaksi sosial secara langsung dapat terjalin. Selain itu juga adanya jaringan sosial online berupa WhatsApp Group dan Facebook yang memudahkan berbagi informasi terkait pengalaman, keadaan, dan kegiatan terkait komunitas tersebut. Modal sosial inilah yang berfungsi untuk mempertahankan eksistensi dari komunitas tersebut.

Jika modal telah dimiliki oleh para penggemar miniatur truk, maka kemudian yang dapat dilihat dari penggemar tersebut adalah segala aktivitasnya yang berhubungan dengan miniatur truk. Hal itu sama dengan konsep Habitus yang diperkenalkan oleh Bourdieu. Penggemar miniatur truk dengan segala modal yang dimilikinya melakukan aktivitas dengan segala pengetahuannya tentang miniatur truk untuk bertempur dalam arena karnaval. Habitus mereka dalam dunia miniatur truk dapat dilihat dari proses bagaimana mereka membuat miniatur truk itu sendiri. Mereka saling berrelasi sosial di antara para penggemarnya untuk saling bertukar pikiran demi terciptanya sebuah miniatur.

\subsection{Kanal Media Sosial sebagai Jaringan Berbagi antar Penggemar Miniatur Truk}

Habitus berupa hubungan sosial di antara penggemar juga termanifestasi dalam dunia maya, di mana media sosial dijadikan alat untuk saling berbagi informasi tentang miniatur truk. Youtube memainkan peran sangat penting dalam memperkaya khasanah perminiaturan. Video-video dalam youtube merupakan sumber referensi bagi penggemar, baik untuk meningkatkan kreativitas maupun untuk mengakui lebih baik mana miniatur yang dibuat. Sementara itu, facebook digunakan penggemar untuk bertukar informasi terkait event perlombaan, 
memamerkan karya, dan memamerkan telah tampil di suatu karnaval sebagai wujud eksistensi. Facebook juga digunakan untuk membuat grup-grup penggemar miniatur. Setidaknya dua media sosial di atas sangat berperan dalam membantu aktivitas para penggemar miniatur truk.

Payung besar Habitus penggemar miniatur truk tidak lain adalah menampikan karya-karya miniaturnya dalam event karnaval. Mereka dengan segala modal yang ada datang dan ikut iring-iringan menarik miniatur truknya dengan berjalan kaki menyusuri jalur yang telah ditentukan oleh panitia. Tidak lupa, lantunan musik DJ remix yang khas miniatur truk juga dipersembahkan melaui sound system dengan bunyi yang sangat kuat. Mereka hadir untuk saling berkompetisi dari satu event ke event lain, baik dalam satu kabupaten maupun kabupaten lain. Terkadang apa yang mereka inginkan bukan sekadar hadiah yang ditawarkan, namun rasa bangga atas pengorbanan yang telah dilakukan. Tidak hanya itu, bagi sebagian penggemar, pengakuan juga dibutuhkan. Memenangkan sebuah kompetisi miniatur truk adalah sebuah bentuk pengakuan.

Segala habitus dan modal penggemar miniatur truk sejatinya terkungkung dalam sebuah arena, yaitu arena miniatur truk, di mana sejak penggemar memulai untuk membuat miniatur, berelasi dengan sesama penggemar, dan menampilkan karyanya dalam sebuah karnaval, mereka telah berkompetisi dalam sebuah arena. Arena inilah yang kemudian oleh Bourdieu disebutnya sebagai tempat untuk saling merebutkan sumber daya. Oleh karenanya, arena dalam fenomena miniatur truk tidak sebatas pada arena karnaval untuk menampilkan karya miniaturnya. Namun sejak penggemar memutuskan untuk menjadi aktor dalam memainkan miniatur truk, di mana perebutan sumber daya (modal) mulai dimainkan.

Arena miniatur truk juga termasuk relasi-relasi sosial pertemanan antar-anggota penggemar miniatur, baik yang dilakukan secara langsung melalui pertemuan, maupun melalui media sosial. Pertukaran sosial yang terjadi merupakan ladang bagi penggemar untuk saling memperebutkan sumber daya yang ada. Habitus dan modal yang melekat pada penggemar miniatur dan dimainkan dalam sebuah arena inilah yang kemudian dapat dikatakan sebagai praktik sosial yang dikenalkan oleh Pierre Bourdieu.

Dapat dilihat bahwa pertaruhan utama dalam arena miniatur truk adalah memonopoli legitimasi kekuasaan untuk mengatakan berdasarkan otoritas siapa yang berhak menyebut dirinya sebagai raja dari pawai miniatur truk yang salah satunya ditunjukkan oleh pergulatan antarpeserta. Peserta dengan modal yang mumpuni akan merasa bahwa ia mempunyai sumber daya dalam mempertahankan prestisnya. Peserta pawai berusaha untuk memburu legitimasi tersebut dengan melakukan suatu praktik yang di dalamnya terakumulasi modal dan strategi-strategi tertentu yang berimplikasi pada perubahan struktur arena (Bourdieu, 2010).

"Nama besar" yang didapat dari kontestasi arena miniatur truk menjadi hal krusial sebab melalui definisi itulah seorang peserta mendapatkan konsekrasi atau derajat pengakuan yang memberinya peluang untuk meraih posisi tertentu di arena miniatur truk (Bourdieu, 2011). Perspektif khas inilah yang bisa digunakan untuk membongkar atau menyingkap dominasi (praktik kuasa) yang ada dalam arena miniatur truk, seperti kepentingan-kepentingan dominatif di balik apa yang disebut sebagai selera budaya.

Secara implisit, kuasa simbolik tersebut berfungsi agar raja miniatur truk bisa mengupayakan untuk membuat cara pandang peserta lain menyangkut persepsi dan apresiasi bergerak pada arah tertentu (Deer, 2008), sehingga arena miniatur truk merupakan tanah perjuangan yang memuat relasi-relasi sosial terdiri atas pertarungan memperebutkan posisi sebagai pemenang dengan melakukan rekonversi modal ekonomi dengan cara membuat miniatur truk yang paling bagus untuk diinvestasikan dalam bentuk modal kultural sehingga memperoleh modal simbolik. 


\section{Kesimpulan}

Fenomena sosial pawai miniatur truk merupakan praktik budaya baru dalam masyarakat rural, khususnya yang ada di daerah Jawa Timur bagian Selatan, meliputi Kabupaten Malang, Kabupaten Blitar, Kabupaten Tulungagung, dan Kabupaten Kediri. Teori Praktik Sosial yang diperkenalkan oleh Pierre Bourdieu sangat relevan untuk mengalisis fenomena pawai miniatur truk ini, di mana modal ekonomi yang digunakan oleh penggemar untuk membuat sebuah miniatur merupakan representasi konsep modal menurut Pierre Bourdie. Modal simbolik berupa prestise dan nama besar komunitas yang telah ada sejak lama serta relasi sosial di antara penggemar miniatur juga merepresentasikan konsep modal.

Sementara itu, segala aktivitas penggemar miniatur yang berhubungan dengan dunia perminiaturan secara komprehensif dapat dianalisis dan sesuai dengan konsep habitus yang diperkenalkan oleh Pierre Bourdieu. Modal dan habitus yang dimiliki oleh penggemar miniatur tersebut dimainkan ke dalam sebuah ruang, di mana ruang tersebut merupakan tempat pertarungan para penggemar dalam merebutkan sumber daya. Ruang tersebut adalah ruang sejak penggemar memutuskan untuk menjadi aktor dalam dunia perminiaturan. Ruang inilah yang disebut oleh Pierre Bourdieu sebagaiu arena.

Pembahasan ini pada akhirnya menemukan sebuah konsep baru tentang praktik sosial dalam hiburan masyarakat rural, di mana pawai miniatur truk telah menjadi sebuah praktik sosial warga pedesaan di daerah Jawa Timur bagian Selatan. Budaya baru ini akan menjadi identitas masyarakat setempat yang patut untuk dihargai. Fenomena miniatur truk yang terjadi menambah khasanah pengetahuan dan penguatan teori khususnya teori Praktik Sosial yang diperkenalkan oleh Pierre Bourdieu.

\section{Daftar Pustaka}

Blitar, A. (Producer). (2019). Sound \& truk miniatur Blitar. Retrieved from https://www.youtube.com/watch?v=pld wU2mnNxU

Bourdieu, P. (2002). Forms of Capital. In N. W. Biggart (Ed.), Economic Sociology. Massachussets: Blackwell Publisher.

Bourdieu, P. (2010). Arena Produksi Kultural. Yogyakarta: Pustaka Pelajar.

Bourdieu, P. (2011). Choses Dites: Uraian dan Pemikiran. Yogyakarta: Kreasi Wacana.

Deer, C. (2008). Reflexifity. In M. Grenfell (Ed.), Pierre Bourdieu: Key Concepts. Durham: Acumen Publishing.

Denissa, L., Pialang, Y. A., Widodo, P., \& Adidsasmito, N. Y. D. (2016). Fenomena Intertekstualitas Fashion Karnaval di Nusantara. Panggung, 26(4), 430-443. doi: http://dx.doi.org/10.26742/panggung.v2 6i4.214.g242

Denissa, L., Widodo, P., Adisasmito, N. D., \& Piliang, Y. A. (2015). Public Engagement and the Making of Carnaval's Place at Jember Fashion Carnaval. Procedia - Social and Behavioral Sciences, 184, 95-103. doi:https://doi.org/10.1016/j.sbspro.201 $\underline{5.05 .061}$

Dona, M. (2019). Angkat Potensi Desa, TPS di Blitar ini Bertema Truk. faktualnews. Retrieved from https://faktualnews.co/2019/04/17/angk at-potensi-desa-tps-di-blitar-inibertema-truk/135356/

Facebook (2020a). Komunitas Miniatruk Truk Blitar Raya Retrieved from https://web.facebook.com/groups/16731 8890474543/ 
Facebook (2020b). Komunitas Miniatur Kediri Selatan Retrieved from https://web.facebook.com/groups/15997 91106699596/

Facebook (2020c). Komunitas Sound Miniatur Truk Malang Raya. Retrieved from

https://web.facebook.com/groups/11032 $\underline{55149759030 /}$

Facebook (2020d). Miniatrur Truk Tulungangung Retrieved from https://web.facebook.com/groups/33403 1020658099/

Facebook (2020e). Pecinta Miniatur Sound System dan Truk Plat AG. Retrieved from

https://web.facebook.com/groups/19896 88571285448/

Hadi, S. (2018). Penggemar Miniatur Truk di Blitar Makin Banyak, Harga Truk Capai Rp 5 juta. jatim tribun news. Retrieved from

https://jatim.tribunnews.com/2018/06/2

6/penggemar-miniatur-truk-di-blitarmakin-banyak-harga-truk-capai-rp-5juta

Hasanah, U. (2019). Arak-Arakan Simbol Warak Ngendog Sebagai Media Dakwah. Al-I'lam: Jurnal Komunikasi dan Penyiaran Islam, 3(1). doi:https://doi.org/10.31764/jail.v3i1.13 $\underline{67}$

Ibnu, S. (Producer). (2018). Lucunya TRUK MINIATUR di Kras Kediri - Karnaval Desa Butuh. Retrieved from https://www.youtube.com/watch?v=lIpk $\underline{\text { PuZohhU }}$

Malang, K. A. (Producer). (2019). Pengarajin Miniatur Truk Murni Rakitan Bayu Kodok Ngesot. Retrieved from https://www.youtube.com/watch?v=Oi WY2WpQVKI

Ratri, N. (2018). Unik, Parade 75 Minitruck Bakal Ikut Pesta Rakyat Sadar Pajak di
Malang. Malang Times. Retrieved from https://www.malangtimes.com/baca/332 50/20181116/184500/unik-parade-75minitruck-bakal-ikut-pesta-rakyatsadar-pajak-di-malang

Ritzer, G., \& Goodman, D. J. (2010). Teori Sosiologi: Dari Teori Sosiologi Klasik Sampai Perkembangan Mutakhir Teori Sosiologi Postmodern (Nurhadi, Trans.). Yogyakarta: Kreasi Wacana.

Santoso, G. (Producer). (2019). Festival Miniatur Truck di Tunjung Udanawu Blitar 19119. Retrieved from https://www.youtube.com/watch?v=Ap uVhH4vAHM

Siregar, M. (2016). Teori "Gado-gado" Pierre-Felix Bourdieu Anlmage Jurnal Studi Kultural, 1(2), 79-82. Retrieved from

https://journals.an1mage.net/index.php/ ajsk/article/view/61

Sutik, E. (Producer). (2020). Parade Miniatur Truck Sound Wates Campurdarat Tulungagung. Retrieved from https://www.youtube.com/watch? $\mathrm{v}=\mathrm{uC}$ wFzjtSZoQ

Syaifuddin, M. A., Qodariah, L., \& Naredi, H. (2019). Modal Sosial Komunitas Motor Tua Japs Bratstyle Indonesia: Studi Kasus Paspampres, Jakarta Timur Chronologia, doi:https://doi.org/10.22236/jhe.v1i2.47 $\underline{17}$

Wahjuni, S., \& Al-Balya, M. D. (2020). Parade Miniatur, Potensi Pariwisata Berbasis Komunitas di Kabupaten Kediri Journal of Tourism and Creativity, 4(1), 31-42. doi:https://doi.org/10.19184/jtc.v4i1.14 $\underline{355}$

Wati, K. S. (2015). Modal dalam Praktik Sosial Arisan Sosialita (Studi Fenomenologi Terhadap Dua Kelompok Arisan Sosialita di Malang dan Jakarta). Idea Societa, 2(5), 1-27. Retrieved from 
http://jmsos.studentjournal.ub.ac.id/inde x.php/jmsos/article/view/103/121

Windarti, Y. (2016). Communities Inclusion of Urban Tourism Development: The Case of Bandung City, Indonesia. International Journal of Culture and History, 2(4), 189-198. doi:https://doi/org/10.18178/ijch.2016.2 .4 .062 